\title{
Primærforebyggende alkoholundervisning i ungdomsskolen: Positive korttidseffekter
}

\author{
Britt Unni Wilhelmsen ${ }^{1,3}$ og Jon Christian Laberg ${ }^{2}$ \\ ${ }^{1}$ HEMIL-senteret, Universitetet i Bergen \\ ${ }^{2}$ Institutt for samfunnspsykologi, Universitetet i Bergen \\ ${ }^{3}$ Adresse for korrespondanse: Førsteamanuensis Britt Unni Wilhelmsen, Høgskolen i Bergen, Landåssvingen 15, 5030 Landås \\ Tlf. 555957 00, fax 555958 09, e-mail Brittuw@Lsv.Hib.No
}

\begin{abstract}
SAMMENDRAG
Et forebyggende prosjekt om alkohol for 13-14 åringer er gjennomført ved Universitetet i Bergen. Målsettingen for prosjektet var å utsette debutalder for drikking og redusere eksperimentering med alkohol. Elevene deltok i 10 timer prosjektorientert undervisning, som bygget på korrigering av elevenes alkoholforventninger og flertallsmisforståelser om alkohol. Resultatene på kort sikt var positive: Ingen prosjektelever rapporterte alkoholdebut fem måneder etter prosjektstart. Blant elever som eksperimenterte med alkohol før prosjektstart, ble det registrert en nedgang på $25 \%$. Elever som gjennom prosjektet hadde redusert sine forventninger til alkohol, hadde også redusert alkoholbruk. To ulike strategier for å øke elevenes involvering i prosjektet ble prøvd ut, og størst elevinvolvering ble observert når lærere, gruppeledere og elever fikk klare retningslinjer for sine roller i prosjektet. Videre arbeid med primærforebyggende alkoholundervisning i skolen bør ta utgangspunkt i elevenes egne forestillinger om alkoholbruk. Det er behov for forskning som kan bidra til å sikre varige effekter av alkoholforebyggende tiltak.
\end{abstract}

\section{PRIMARFOREBYGGENDE ALKOHOL- UNDERVISNING I UNGDOMSSKOLEN: POSITIVE KORTTIDSEFFEKTER}

Rusmiddelbruk blant unge er et av de spørsmål som opptar den voksne befolkning mest, delvis på grunn av nyheter om økende bruk av vanedannende stoffer blant unge, og de helsefarer dette fører med seg. Ungdom selv er også opptatt av at rusmiddelbruk kan bety alvorlige helseproblemer. F.eks. fant Raundalen og Raundalen (1) at røyking, narkotika og alkohol var tre helseproblemer som oftest ble nevnt blant 7.klassinger som ble spurt om hvilke alvorlige helseproblemer de står overfor i årene fremover.

Tobakk og alkohol er de mest brukte rusmidlene blant ungdom, mens en mindre gruppe eksperimenterer med ulovlige rusmidler (2). En større internasjonal WHO-undersøkelse viste at det allerede i 5 . klasse er $34 \%$ av guttene og $21 \%$ av jentene som rapporterer å ha drukket alkohol. Andelen som har drukket øker raskt fra 5. til 9. klasse. I 9. klasse oppga 4 av 5 elever å ha drukket alkohol, og forskjellen mellom jenter og gutter ser ut til å forsvinne. En nyere WHOundersøkelse (3) bekrefter disse funnene. Langt flere gutter $(30,8 \%)$ enn jenter $(16,6 \%)$ har drukket alkohol i 5. klasse, og kjønnsforskjellen er helt utvisket i 9. klasse, hvor $79,7 \%$ av begge kjønn har drukket.

I Sosialdepartementets Stortingsmelding nr. 37, 1992-93 (4), er rusproblemer pekt på som et av flere psykososiale satsningsområder for helsefremmende og forebyggende arbeid i Norge. Meldingen fokuserer på skolen som en viktig arena for dette arbeidet (s. 5758). I skolen gjennomføres ulike former for forebyggende tiltak om alkohol, f.eks. er det ikke uvanlig å bruke tørrlagte alkoholikere som forebyggere for elevene. Et viktig spørsmål er hvorvidt de tiltakene skolen tilbyr elevene har en forebyggende effekt, dvs. resulterer i utsatt debutalder for drikking eller mindre alkoholbruk blant unge.

Ulike yrkesgrupper som lærere, helsepersonell og politi har et pålagt ansvar for primærforebyggende tiltak om alkohol for barn og unge. Rusforebyggende opplegg gjennomføres årlig i lokalmiljøene utover i landet vårt. Det sentrale spørsmålet er om yrkesgrupper med ansvar for primærforebyggende arbeid om alkohol, vet nok om det forebyggende potensialet som ligger i tiltak som prøves ut. Det er på sin plass å reise følgende spørsmål: Hva vet ansvarlige for rusforebyggende arbeid om effekter av ulike typer tiltak om alkohol? Hva kan gjøres for å øke 
kunnskapen om effektive rusforebyggende tiltak for å oppnå utsatt alkoholdebut og redusert alkoholbruk blant barn og unge?

\section{EVALUERINGSFORSKNING}

Evaluering er nødvendig for å skaffe kunnskaper om effekter av forebyggende tiltak om alkohol. Hensikten med evalueringsforskning er først og fremst å øke kunnskapen om forebyggende prosjekter med et helsefremmende potensiale. Samtidig gir slik forskning innsikt i hvilke forebyggende tiltak vi ikke bør satse på, enten fordi de ikke gir effekt eller fordi de pirrer elevenes nysgjerrighet til å prøve ut rusmidler, og dermed gir negativ effekt. Ved inngangen til et nytt århundre har vi relativt gode kunnskaper om hvilke strategier vi bør velge for å oppnå forebyggende resultater av skolebaserte prosjekt om alkohol. Flere meta-analyser (5-8) trekker opp entydige retningslinjer for rusforebyggende arbeid ut fra evalueringer som er gjennomført.

"Kunnskapsbaserte opplegg” forutsetter at kunnskaper om skadevirkninger av alkohol forebygger alkoholbruk. Evalueringer viser at slike opplegg øker kunnskaper om alkohol uten å ha særlig virkning på alkoholatferd. "Alternative opplegg" forsøker å redusere alkoholbruk ved å aktivisere elevene uten å fokusere på et «nei til alkohol»-budskap. Registrerte negative effekter av denne type opplegg gjør at forskere advarer mot "Alternative opplegg". Såkalte "Affektive opplegg" antar at unge bruker rusmidler fordi de har lav selvtillit og mangler evne til å ta avgjørelser og løse problemer. En antar at ved å utvikle slike ferdigheter hos elevene, vil de gjøre «de rette» valg med hensyn til alkoholbruk. Fokus for "Affektive opplegg” er mot generelle mål (bredere mestringsferdigheter) mer enn mot et «nei til alkohol»-mål. Evalueringer gir ingen støtte for at slike opplegg er effektive i å forebygge alkoholbruk blant unge.

"Sosial-kognitive opplegg" eller "Sosial påvirknings-opplegg" viser seg å ha det største forebyggende potensialet som strategi for å redusere alkoholbruk blant unge, selv om resultatene fra evalueringer foreløpig bare viser moderate positive effekter. Et viktig kjennetegn på slike opplegg er et forsøk på å påvirke det sosiale miljøet for alkoholbruk. Videre satser slike tiltak på å endre unges forestillinger om alkohol og alkoholbruk. Det kan f.eks. være å redusere positive forventninger til virkninger av drikking, å korrigere flertallsmisforståelser («alle unge drikker»), å styrke forventninger om å mestre drikkepress og å styrke sosiale normer for å la være å drikke.

Den forebyggende strategien for forskningsprosjektet «Unge og rusmidler», gjennomført i Bergen 1991-1994 med midler fra Forskningsrådet, Bergen kommune og Universitetet i Bergen, var basert på erfaringer fra tidligere evalueringsstudier både i Norge og internasjonalt (5-9).

\section{ÅRSAKER TIL 13-14 ÅRINGERS ALKOHOLBRUK}

I Bergensprosjektet "Unge og rusmidler" (10) var vi opptatt av årsaker til drikking blant 13-14 åringer. Vi undersøkte hvilken betydning holdninger, subjektive normer og forventninger hadde som prediktorer for alkoholbruk og intensjoner om å drikke. Vi fant at det i hovedsak var subjektive normer og forventninger (mestringsforventninger og alkoholforventninger) som predikerte alkoholbruken blant 7 . klassinger. Elever med høye forventninger til virkninger av drikking var de som hadde størst drikkefrekvens og de høyeste intensjonene om å drikke $(10,11)$.

På bakgrunn av disse resultatene satte vi opp følgende målsettinger for vårt primærforebyggende prosjekt: $\AA$ forebygge alkoholdebut og redusere eksperimentering med alkohol blant 13-14 åringer gjennom 1) å styrke elevenes sosiale normer for å la være å drikke, 2) å styrke elevenes forventninger om å mestre drikkepress, 3) å redusere elevenes forventninger om positive virkninger av alkoholbruk. Utgangspunktet for å utvikle en arbeidsplan i Bergensprosjektet «Unge og rusmidler» ble dermed å påvirke alkoholbruk gjennom å påvirke viktige årsaker til alkoholbruk blant 13-14 åringer.

\section{UNDERVISNINGSOPPLEGGET}

Bergensprosjektet «Unge og rusmidler» hadde følgende strategi: Elevene skulle selv finne løsninger på spørsmålet «Hvorfor bruker ungdom alkohol?». Deltakerstyring sto sentralt i prosjektet: både elever, lærere og skolens helsepersonell hadde viktige roller $i$ prosjektet. Spesielt ble elevaktiviteten satt i sentrum, og fire gruppeledere fra hver klasse fikk ansvar for gjennomføringen av ca. halvparten av opplegget (10). Gruppeledernes oppgave var å lede smågruppediskusjoner og rollespill. Hver klasse valgte sin målsetting for prosjektet. Det kunne være i) å formidle et «nei til alkohol»-budskap til yngre elever, foreldre eller media, ii) lage klasseavis eller iii) organisere foreldrekveld som mål for prosjektet.

En undervisningsplan med fire tema ble utviklet: 1) Lokale tradisjoner for alkoholbruk blant unge, 2) Sosiale normer for alkoholbruk blant unge, 3) Mestring av drikkepress og 4) Holdninger til alkoholbruk. Elevene skulle snakke om lokale drikketradisjoner i nærmiljøet, drøfte konsekvenser av tradisjonene og finne alternativer til alkoholbruk blant unge. Deretter skulle de selv undersøke hva viktige andre (foreldre, søsken, eldre ungdom, ungdomsledere m.fl.) mente om at 13-14 åringer bruker alkohol. Informasjonen 
elevene hentet inn ble diskutert på skolen, og hensikten med oppgaven var å få frem betydningen av restriktive normer for ungdomsdrikking.

Elevene skulle lage hypoteser om drikkefrekvens blant 7. og 9. klassinger, og deretter, via en "Nyhetsavis", få presentert data som var hentet inn fra 7. og 9. klassene et år tidligere. Hensikten med denne oppgaven var å korrigere feiloppfatninger om drikkefrekvens og dokumentere at det er relativt få som drikker. Gjennom rollespill skulle elevene trene på å bli utsatt for drikkepress, være den som presser eller den som støtter presseren. Elevene skrev også brev til seg selv som 9. klassinger hvor de argumenterte med hvorfor de ikke skulle drikke. Som avslutning på prosjektet kunne klassene velge om de ville sende et budskap til foreldregruppen, til yngre elever, til aviser eller på stand på skolen eller et annet sted i nærmiljøet.

Hvert tema fikk en tidsramme på 2 timer. I tillegg ble det avsatt en time til innføring i prosjektet og en til avslutning av prosjektet. Total tidsramme på 10 skoletimer ble fordelt over fem uker med to prosjekttimer hver uke. I tillegg til skoletimene fikk elevene gruppeoppgaver som ble gjennomført i lokalmiljøet. Undervisningsplanen ble nedfelt $\mathrm{i}$ en manual for lærere og en for gruppeledere.

\section{STUDIEGRUPPE OG DESIGN}

Ca. 1000 elever og 42 lærere fra 12 ungdomsskoler i Bergen kommune deltok i prosjektet skoleårene 1991/92 og 1992/93. Spørreundersøkelser ble gjennomført før (januar 1992) og etter (mai 1992) undervisningsopplegget.

Skolene ble fordelt $\mathrm{i}$ en kontroll- og to intervensjonsgrupper. I en gruppe som besto av 4 skoler fikk lærere og elever sterk spesifisering av sine roller $\mathrm{i}$ prosjektet. Utleverte manualer beskrev arbeidsoppgaver og -funksjoner, og aktørene ble trent opp til å utføre sine roller på en forhåndsbestemt måte. I en annen gruppe som besto av 4 skoler ble det gitt mindre spesifisering av de roller lærere og gruppeledere skulle ha. Lærere i begge intervensjonsgruppene fikk et to-dagers kurs for å få informasjon om opplegget. Elever fra intervensjonsklassene fikk opplæring i å være gruppeledere for smågruppediskusjoner og rollespill, og de fikk trening i å gi klare normative budskap i de ulike diskusjonstemaene. Kontrollgruppen (4 skoler) hadde skolenes vanlige rusforebyggende opplegg, og 7. klassingene på disse skolene deltok bare i de to spørreundersøkelsene i Bergensprosjektet.

\section{PROSJEKTGJENNOMFØRING}

Klassene (og foreldre/andre i kommunen) fikk innføring i prosjektet via prosjektets første «Nyhetsavis» og via en orientering på skolen gitt av lærer og gruppeledere som hadde deltatt i en skolering før prosjektstart. I smågrupper diskuterte elevene lokale drikketradisjoner i nærmiljøet, de drøftet konsekvenser av slike tradisjoner og de presenterte alternativer til alkoholbruk i egen aldersgruppe. Elevene undersøkte også hva viktige andre (foreldre, søsken, eldre ungdom, ungdomsledere m.fl.) mente om at 13-14 åringer bruker alkohol, og diskuterte sine funn på skolen.

Klassen hadde som oppgave å utvikle sin strategi for å si nei takk til alkohol. Etter rollespillet diskuterte elevene sine opplevelser av de ulike rollene og hvilke metoder som best egner seg for å kunne si nei takk til alkohol. Elevene skrev brev til seg selv som 9. klassinger hvor de argumenterte for hvorfor det er viktig å utsette alkoholdebut. Som avslutning på prosjektet gjennomførte klassene den målsettingen de hadde valgt: f.eks. å gi et forebyggende budskap til foreldre, yngre elever eller aviser, eller presentere prosjektet på stand på skolen eller et annet sted i nærmiljøet (f.eks. et kjøpesenter).

\section{RESULTATER}

\section{Alkoholatferd}

Analyser av data fra den første undersøkelsen (januar 1992) viste at 30\% av 13-14 åringene i hele utvalget rapporterte å ha prøvd alkohol (lettvin, pils, vin, brennevin). Pils var den alkoholtypen som ble hyppigst brukt. Data fra første etterundersøkelse (mai 1992) viste at ingen elever uten alkoholbruk ved forundersøkelsen hadde begynt å bruke alkohol. Det var dermed ingen nyrekruttering til alkoholbruk $\mathrm{i}$ prosjektperioden. Blant elever som deltok i SSundervisningen, ble det rapportert en nedgang $i$ eksperimentering med alkohol fra 20 til 15\%, mens kontrollgruppen var uendret (fortsatt 20\%). Det indikerer at undervisningen klarte å påvirke en fjerdedel av de elevene som eksperimenterte før opplegget ble gjennomført.

Blant elever som fikk undervisning ble det ikke registrert en økning i antall elever som rapporterte regelmessig drikking. I kontrollgruppen fant vi derimot $2 \%$ flere elever som drakk hver uke eller hver måned. Vi tolker disse resultatene slik at undervisningen hindret flere elever $i$ å gå inn i et regelmessig drikkemønster. Andre etterundersøkelse (januar 1993) viste ikke forskjeller mellom intervensjons- og kontrollelevene.

\section{Alkoholforventninger}

Vi var også interessert i hvilken betydning alkoholforventninger, målt ved hjelp av Goldman og Christiansen's “Alcohol Expectancy Questionnaire" $(12,13)$, hadde for elevenes intensjon om å drikke. Var positive alkoholforventninger årsak til alkohol- 
bruk blant elever i 7. klasse? Før prosjektet startet fant vi at det var en sterk sammenheng mellom intensjon om å drikke og positive forventninger om alkoholens sosiale betydning. Slike sosiale forventninger var også en signifikant prediktor for alkoholbruk (beta $0,19, \mathrm{p}<0,01)$. Derimot fant vi at mer globale, positive forventninger til alkohol ikke signifikant predikerte intensjon om å drikke (14).

Figur 1 viser sammenhengen mellom økende forventninger til alkohol og alkoholbruk blant elever i 7. klasse før prosjektstart. Som det fremgår av figuren er det generelt små kjønnsforskjeller, men gutter med de sterkeste, positive forventningene til alkohol har et konsum som er omtrent syv ganger så høyt som gutter med de svakeste, minst positive forventningene til alkohol. Også blant jenter er det myere høyere konsum hos de som har de mest positive alkoholforventningene, sammenlignet med jenter som har minst forventninger til alkohol.

Figur 2 viser sammenhengen mellom forventninger til alkohol og intensjon om å drikke før og etter prosjektet. Figuren skiller også mellom elever som ved prosjektstart rapporterte at de hadde erfaring med alkohol, og de som sa at de ikke hadde smakt alkohol fra før av. Hvis vi ser på intensjon om å drikke før prosjektstart (hel linje), ser vi at forventninger til alkohol og tidligere drikkeerfaring har en gjensidig forsterkende effekt. Elever som har drikkeerfaring har større intensjon om å drikke jo høyere forventninger de har, mens høyere forventninger spiller mindre rolle for de som ikke har begynt å drikke ennå. De elevene som har høyere intensjon om å drikke etter prosjektet, er først og fremst de som hadde begynt å bruke alkohol før prosjektstart, uavhengig av hvilke forventninger de hadde.

Det var en målsetting for prosjektet å redusere forventninger til alkohol. Når vi så på effekten av de to intervensjonsprogrammene, fant vi at det var en nedgang $\mathrm{i}$ intensjon om å drikke blant elever som hadde reduserte forventninger (se figur 3 ). Vi fant størst nedgang blant elever i HRS-gruppen. Hos de elevene som hadde økte forventninger, var det også økt forbruk av alkohol. Det kan derfor se ut til at det å redusere forventninger til alkohol, særlig hos de som har begynt å drikke, kan bidra til redusert konsum.

\section{KONKLUSJONER}

Det store flertallet av 13-14 åringene i denne undersøkelsen (95-97\%) hadde ikke etablert en regelmessig drikking, men en del hadde begynt å eksperimentere med alkohol. På bakgrunn av data fra 9. klasse viser vår undersøkelse at det er viktig å komme inn med forebyggende undervisning for 13-14 åringer for å hindre den store økningen i regelmessig drikking som ble registrert fra 7. til 9. trinn. Vi vurderer vårt valg av forebyggende strategi som egnet ettersom vi registrerte en relativt stor nedgang i alkoholeksperimentering. Positive effekter på regelmessige brukere kan på den

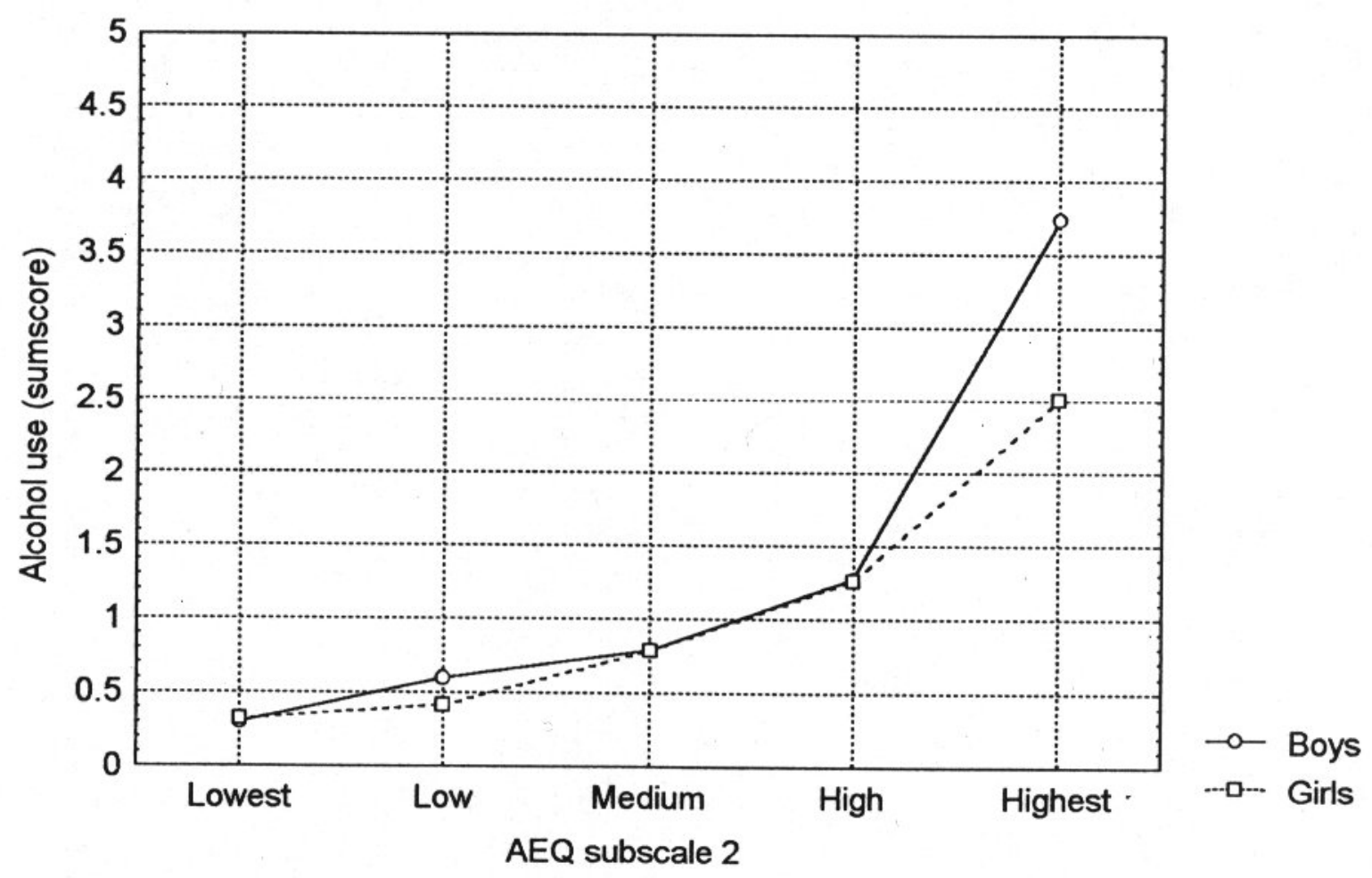

Figur 1. Gjennomsnittlig alkoholbruk hos elever med ulike forventninger til alkohol, målt ved hjelp av "Alcohol Expectancy Questionnaire” skala 2 (“Alcohol use Enhance or Impede Social Behavior”). Gjengitt fra Wilhelmsen, Laberg, \& Aas (14). 
Effects of alcohol outcome expectancies:

"Enhance or impede social behavior"
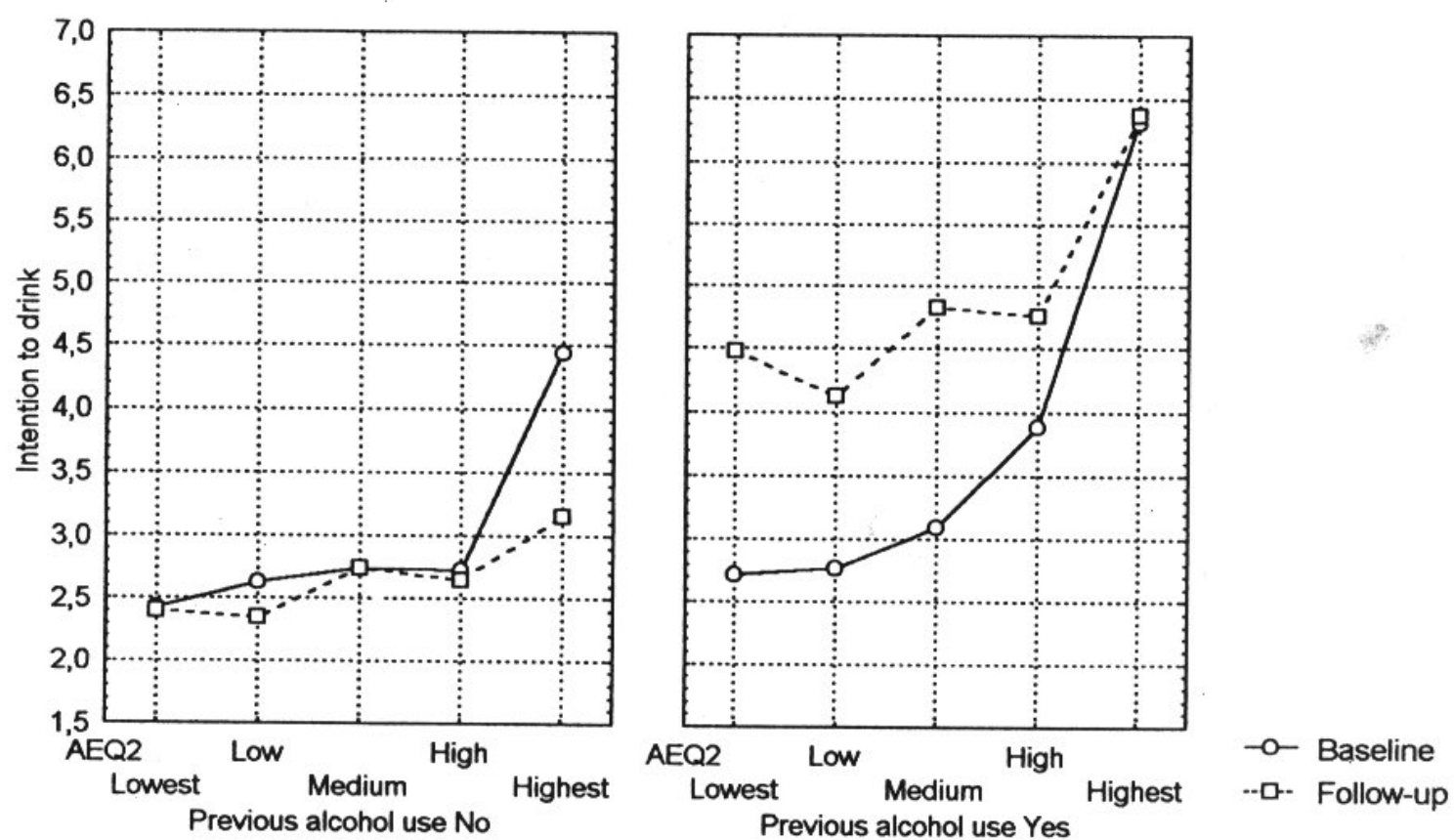

Figur 2. Gjennomsnittlig intensjon om å drikke før og etter prosjektet hos elever med ulike forventninger til alkohol, målt ved hjelp av "Alcohol Expectancy Questionnaire” skala 2. Venstre del viser elever uten tidligere alkoholbruk, høyre del viser elever med tidligere alkoholbruk. Gjengitt fra Wilhelmsen \& Laberg (15).

\section{Endring i intensjon om å drikke i hvert program. \\ Elever med uendrete og økte forventninger. \\ $F(2,835)=1,31 ; p<, 2703$}
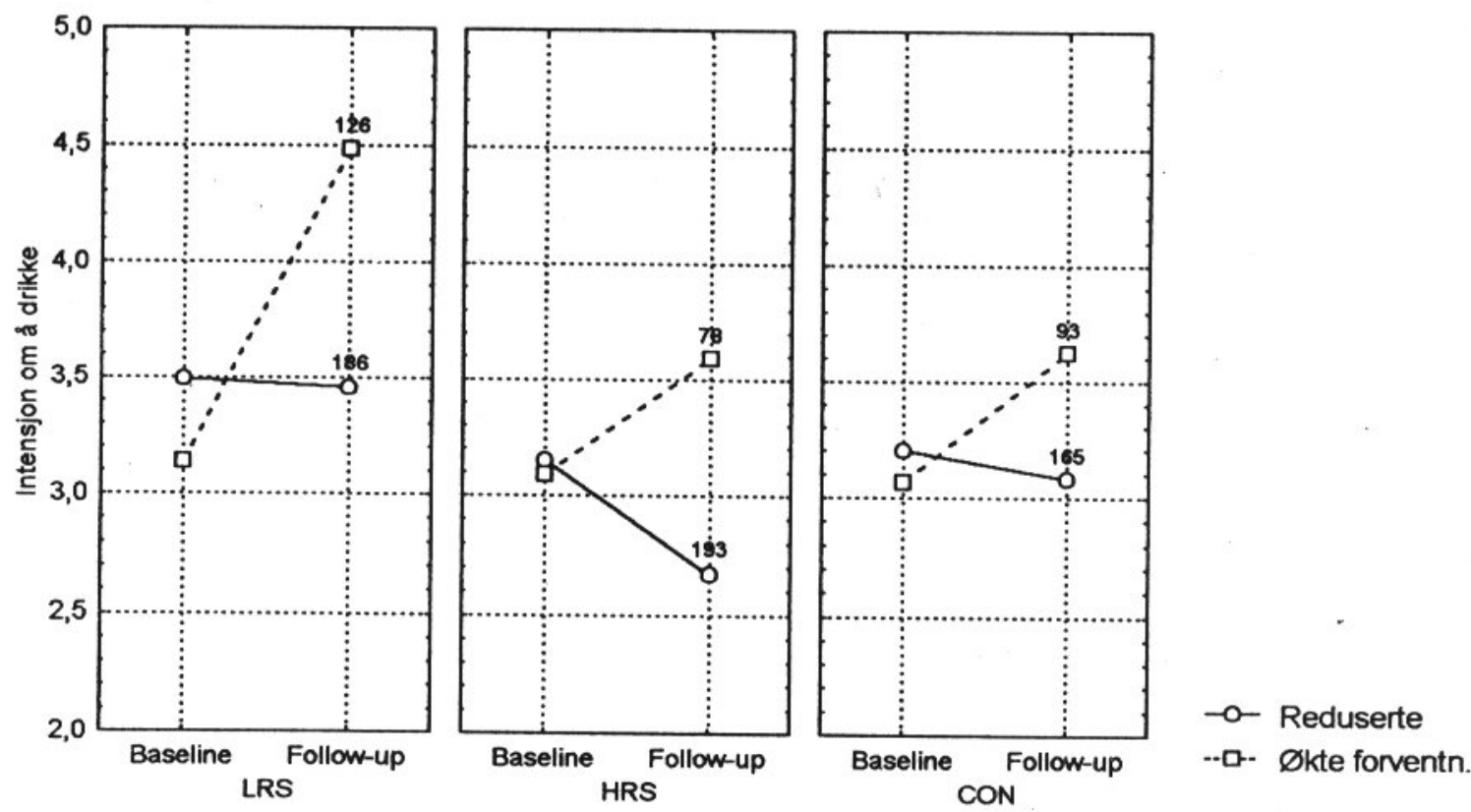

Figur 3. Gjennomsnittlig intensjon om å drikke før og etter prosjektet hos elever med økte og reduserte forventninger til alkohol, målt ved hjelp av "Alcohol Expectancy Questionnaire” skala 2. Venstre del viser elever i den minst rollespesifiserte gruppen, midtre del viser elever i den mest rollespesifiserte gruppen, og høyre del viser elever i kontrollgruppen. Tallene henviser til antall elever i hver gruppe. 
ene siden sies å mangle fordi vi ikke registrerte en nedgang i brukergruppen etter intervensjonen. På den annen side fant vi ikke flere brukere blant elever som deltok i undervisningen, noe som tyder på at opplegget kan ha hindret den økningen vi fant i kontrollgruppen. En mangel på observerte langtidseffekter kan skyldes at den forebyggende undervisningen som ble gjennomført halvveis ut i 7. klasse, må følges opp på 8. og 9. trinn dersom den skal virke over tid.

Et viktig utgangspunkt for å utvikle alkoholforebyggende opplegg, er å vite noe om årsaker til alkoholbruk (16). Kjenner vi til hvorfor ulike ungdomsgrupper drikker, har vi også grunnlaget for å utvikle opplegg med et forebyggende potensiale. Vår undersøkelse viser at både tidlig erfaring med alkohol og sterke forventinger til alkohol er viktige årsaker til videre drikking. For 13-14 åringer er det viktig å tilpasse seg gruppenormene for ikke å skille seg ut fra gruppen. A styrke de unges gruppenormer for å la være å drikke er derfor et viktig moment i det forebyggende arbeidet som politiet, lærere, ungdomsledere, helsepersonell, foreldre og andre tar på seg.

Det er behov for å se effekter over lengre oppfølgingsperioder for vi kan konkludere med at de forebyggende tiltakene gir langtidsvirkning på ungdoms alkoholbruk. Det ville være derfor være ønskelig å møte de utfordringene som ligger i å prøve ut tiltakene i større skala, gitt den positive kortidseffekten som her er observert blant elever i 7. klasse.

\section{REFERANSER}

1. Raundalen, M. \& Raundalen, T.S. (1991). Forurensning, AIDS, atomvåpen, arbeidsledighet og andre framtidsproblemer - slik barn og unge selv ser det. I Klepp, K.I. \& Aarø, L.E. (Red.): Ungdom, livsstil og helsefremmende arbeid. Oslo: Universitetsforlaget, s. 53-56.

2. Aarø, L.E., Wold, B., Kannas, L. \& Rimpelä, M. (1986). Health behaviour in school children. A WHO crossnational survey. Health promotion. I (I): 17-33.

3. Wold, B., Aasen, H., Aarø, L.E. \& Sandal, O. (1995). Helse og livsstil blant barn og unge i Norge. Resultater fra en landsomfattende spørreskjemaundersøkelse tilknyttet "Helsevaner blant skoleelever. En WHOundersøkelse i flere land (HEVAS)”. Bergen: HEMIL-rapport nr. 14.

4. St.meld.nr.37 (1992-93). Utfordringer i helsefremmende og forebyggende arbeid. Oslo: Sosialdepartementet.

5. Norman, E. \& Turner, S. (1993). Adolescent substance abuse prevention programs: Theories, models, and research in the encouraging 80's. Journal of Primary Prevention, 14(1), 3-20.

6. Hansen,W.B. (1992). School-based substance abuse prevention: a review of the state of the art in curriculum, 1980-1990. Health Education Research, 7 (3), 403-430.

7. Bruvold, W.H. \& Rundall, T.G. (1988). A meta-analysis and theoretical review of school-based tobacco and alcohol intervention programs. Psychology and Health, 2, 53-78.

8. Tobler, N.S. (1986). Meta-analysis of 143 adolescent drug prevention programs: Quantitative outcome results of program participants compared to a control or comparison group. Journal of Drug Issues, 16 (4), 537-567.

9. Perry, C.L., Grant, M., Ernberg, G., et al. (1989). W.H.O. Collaborative study on alcohol education and young people: Outcomes of a four-country pilot-study. International Journal of Addiction, 24, 1145-1171.

10. Wilhelmsen, B.U., Laberg, J.C., \& Klepp, K.I. (1994). Evaluation of two alcohol prevention programs for seventh grade students Addiction, 89, 1157-1165.

11. Aas, H., Klepp, K.I., Laberg, J.C., \& Aarø, L.E. (1995). Predicting adolescents' intentions to drink alcohol: Outcome expectancies and self-efficacy. Journal of Studies on Alcohol, 56, 293-299.

12. Christiansen, B.A., Goldman, M.S., \& Inn, A. (1982). Development of alcohol-related expectancies in adolescents: Separating pharmacological from social-learning influences. Journal of Consulting and Clinical Psychology, 50, 336-344.

13. Christiansen, B.A., \& Goldman, M.S. (1983). Alcohol-related expectancies versus demographic/background variables in prediction of adolescent drinking. Journal of Consulting and Clinical Psychology, 48, 419-426.

14. Wilhelmsen, B.U., Laberg, J.C., \& Aas, H. (1995). Alcohol outcome expectancies in adolescence. Innsendt til Psychology and Health.

15. Wilhelmsen, B.U., Laberg, J.C. (1996). Why adolescents drink: Alcohol expectancies and past experience. Innsendt til publisering.

16. Klepp, K.I. (1991). Alkohol, narkotika, tobakk (ant): Primærforebyggende arbeid blant barn og ungdom. I Klepp, K.I. \& Aarø, L.E. (Red.): Ungdom, livsstil og helsefremmende arbeid. Oslo: Universitetsforlaget, s. 139-154. 